\title{
Cancer immunotherapy: how low-level ionizing radiation can play a key role
}

\author{
Marek K. Janiak ${ }^{1} \cdot$ Marta Wincenciak $^{1} \cdot$ Aneta Cheda $^{1} \cdot$ Ewa M. Nowosielska $^{1}$. \\ Edward J. Calabrese ${ }^{2}$
}

Received: 29 July 2016 / Accepted: 22 March 2017 / Published online: 30 March 2017

(C) The Author(s) 2017. This article is an open access publication

\begin{abstract}
The cancer immunoediting hypothesis assumes that the immune system guards the host against the incipient cancer, but also "edits" the immunogenicity of surviving neoplastic cells and supports remodeling of tumor microenvironment towards an immunosuppressive and pro-neoplastic state. Local irradiation of tumors during standard radiotherapy, by killing neoplastic cells and generating inflammation, stimulates anti-cancer immunity and/ or partially reverses cancer-promoting immunosuppression. These effects are induced by moderate $(0.1-2.0 \mathrm{~Gy})$ or high ( $>2 \mathrm{~Gy}$ ) doses of ionizing radiation which can also harm normal tissues, impede immune functions, and increase the risk of secondary neoplasms. In contrast, such complications do not occur with exposures to low doses $(\leq 0.1$ Gy for acute irradiation or $\leq 0.1 \mathrm{mGy} / \mathrm{min}$ dose rate for chronic exposures) of low-LET ionizing radiation. Furthermore, considerable evidence indicates that such
\end{abstract}

Abstract entitled "Cancer immunoedition modified by low-level ionizing radiation" was submitted to the International Conference on Medical Physics, August 03-05, 2015 Birmingham,

UK; abstract is available at the following link: https://www. omicsonline.org/2155-9619/2155-9619.S1.003-015.pdf.

Electronic supplementary material The online version of this article (doi:10.1007/s00262-017-1993-z) contains supplementary material, which is available to authorized users.

Marek K. Janiak

mjaniak@wihe.waw.pl

1 Department of Radiobiology and Radiation Protection, Military Institute of Hygiene and Epidemiology, 4 Kozielska St., 01-163 Warsaw, Poland

2 Department of Environmental Health Sciences, School of Public Health and Health Sciences, Morrill I, N344, University of Massachusetts, Amherst, MA 01003, USA low-level radiation (LLR) exposures retard the development of neoplasms in humans and experimental animals. Here, we review immunosuppressive mechanisms induced by growing tumors as well as immunomodulatory effects of LLR evidently or likely associated with cancer-inhibiting outcomes of such exposures. We also offer suggestions how LLR may restore and/or stimulate effective anti-tumor immunity during the more advanced stages of carcinogenesis. We postulate that, based on epidemiological and experimental data amassed over the last few decades, whole- or half-body irradiations with LLR should be systematically examined for its potential to be a viable immunotherapeutic treatment option for patients with systemic cancer.

Keywords Low-level radiation - Carcinogenesis . Immune suppression $\cdot$ Radio-immunotherapy

\begin{tabular}{|c|c|}
\hline \multicolumn{2}{|c|}{ Abbreviations } \\
\hline $\mathrm{ADCC}$ & Antibody-dependent cellular cytotoxicity \\
\hline DAMP & Damage-associated molecular pattern \\
\hline Gy & $\begin{array}{l}\text { Gray (the SI unit of absorbed dose defined as } \\
\text { the absorption of } 1 \mathrm{~J} \text { of the radiation energy } \\
\text { per } 1 \mathrm{~kg} \text { of matter) }\end{array}$ \\
\hline HBI & Half-body irradiation \\
\hline HMGB 1 & High-mobility group box 1 protein \\
\hline IR & Ionizing radiation \\
\hline LET & Linear energy transfer \\
\hline LLR & Low-level radiation \\
\hline LNT & Linear, no threshold \\
\hline M1, M2 & Macrophage phenotypes 1 and 2 \\
\hline MC & Mast cell \\
\hline mGy & Milligray $(0.001 \mathrm{~Gy})$ \\
\hline $\mathrm{N} 1, \mathrm{~N} 2$ & Neutrophil phenotypes 1 and 2 \\
\hline NHL & Non-Hodgkin's lymphoma \\
\hline NKG2DL & Ligand for the natural killer group 2D receptor \\
\hline
\end{tabular}




$\begin{array}{ll}\text { NKT } & \text { Natural killer T lymphocyte } \\ \text { NOD } & \text { Nucleotide-binding oligomerization domain } \\ \text { PGE }_{2} & \text { Prostaglandin E2 } \\ \text { RT } & \text { Radiotherapy } \\ \text { Th } & \text { Helper T lymphocyte } \\ \text { Treg } & \text { Regulatory T lymphocyte } \\ \text { VEGF } & \text { Vascular endothelial growth factor } \\ \text { WBI } & \text { Whole-body irradiation }\end{array}$

\section{Introduction}

The immune system is a crucial player in the organism's control over the development of neoplasms (reviewed in [1]). After years of controversies, the early concept of cancer immunological surveillance [2,3], whereby specifically stimulated (adaptive) immunity wards off proliferation of neoplastically transformed cells, has now been incorporated into the modern cancer immunoediting process. During the three phases of this process, the anti-neoplastic immune functions and immunogenicity of cancer cells are being gradually "edited", so that the immune system protects the host against the development of a malignancy during the initial "elimination" phase, but later, during the following "equilibrium" and, especially, "escape" phases, morphs into an active supporter of cancer progression. Consequently, the emerging tumor not only evades immune recognition and destruction, but also actively contributes to remodeling of its microenvironment towards the immunosuppressive and pro-neoplastic state [4-10].

The improved understanding of the relationship between a growing tumor and the immune system has shed new light on the recently acknowledged complex interactions of ionizing radiation (IR) with cancer-related immunity. This, in turn, has led to the development of novel radiotherapeutic schemes based on the notion that local exposures at moderate (between 0.1 and 2.0 Gy absorbed during acute exposures) or even high doses (over $2.0 \mathrm{~Gy}$ ) of radiation can, especially in combination with standard immunotherapy, stimulate various anti-neoplastic immune reactions, and/ or reverse their suppressive state. These effects are thought to result from the radiation-induced immunogenic types of cell death, local inflammation, and tissue injury, all leading to the emergence of "danger signals" which prompt activities of the non-specific (innate) immune system; extensive recapitulation of the immunomodulatory effects of local radiotherapy (RT) has recently been summarized in a number of excellent reviews [11-20]. However, even moderate radiotherapeutic doses are potentially harmful to the surrounding normal tissues, which can cause immunosuppression and/or induce secondary cancers [21-23]. Such complications are highly unlikely after exposures to low doses $(\leq 0.1$ Gy absorbed within a short time or $\leq 0.1 \mathrm{mGy} / \mathrm{min}$ dose rate applied during a protracted exposure) of low linear energy transfer (LET) IR, referred to in this paper as low-level radiation (LLR). Indeed, the effects of exposures to LLR, including modulation of the immune functions, can qualitatively and quantitatively differ from those induced by moderate-to-high doses of low-LET radiation [24-29].

The present paper indentifies and evaluates epidemiological as well as animal studies which indicate that exposures to LLR can inhibit or retard the development of primary and metastatic cancers [27, 30-91]. This evaluation will include an assessment of possible mechanisms by which such protective effects may be mediated including: LLR-induced scavenging of reactive chemical intermediates, stimulation of the repair of the DNA damage, mitigation of inflammation, triggering of selective apoptosis or senescence of aberrant cells, and the up-regulation of both the innate and adaptive arms of the anti-cancer immune system [25, 92-95]. Since enhancing anti-neoplastic immunity may be an important mechanism of the cancer-inhibitory effects of LLR [93-101], clinical trials of whole- or half-body irradiations (WBI or HBI) with LLR are also evaluated [102-106].

This paper will also assess how LLR can affect and modify advanced phases of cancer development resulting in a reversal of suppressed immune functions and/or restoration of the susceptibility of cancer cells to the assaults by immune effectors. However, in contrast to the extensively reviewed relations between moderate- and high-dose RT and the response of the immune system, recapitulations of the similar effects of LLR in the context of their clinical exploitation are virtually nonexistent. The present paper will complement and extend a recent review of the vast preclinical evidence of the LLR-induced protective/adaptive response in normal but not neoplastic tissues, which provides arguments for the trials of the LLR-based therapy of cancer [29].

\section{Immunosuppressive tumor microenvironment}

The concept that in vertebrates, elements of the immune system specifically recognize and eliminate incipient neoplastic cells and protect thereby against the development of overt malignancy dates back to late 1950s [2, 3]. In accordance with this "cancer immunosurveillance" hypothesis, it was demonstrated that both immuno-compromised human patients and experimental animals are at increased risk of developing various neoplasms (reviewed in [107]). However, investigations by Stutman showed that chemically induced sarcomas or adenomas do not develop more often in athymic, T-cell-deficient, nude mice than in their widetype, immunocompetent counterparts [108]. This observation seriously challenged the cancer immunosurveillance 
model and almost led to its abandonment [7]. Yet, evidence accumulated in recent years has helped to explain what was wrong with the original cancer immunosurveillance hypothesis and why some neoplasms progress to their clinical stage. Thus, it was found that innate immunity initially senses the presence of transformed cells and exercises the first line of anti-cancer defense. Soon after the activation, elements of the innate immune system promote induction of adaptive (specific) anti-tumor responses. However, owing to genetic and epigenetic changes in the developing neoplastic cells, tumors may become "invisible" to immune effectors through loss or aberrant expression of the MHC class I antigens (reviewed in $[109,110]$ ) or of other molecules on cancer cells involved in triggering of the innate and/or adaptive immune responses [111, 112]. For example, a change in hydrophobicity of tumor cells may lead to suppressed expression of the "damage-associated molecular pattern" (DAMP) molecules necessary to alert the innate immune system to a "danger" incurred by the presence of aberrant cells [113]. Notably, even the "danger signals", such as high-mobility group box 1 protein (HMGB1), can actually support cancer growth through stimulation of myeloid-derived suppressor cells (MDSCs) [114] or nurse-like cells [115] that create conditions favorable for cancer progression. Furthermore, tumor-associated specific antigens may assume forms similar to those expressed on normal cells and evade recognition as "non-self" by the immune system (reviewed in [116]).

Developing tumors create microenvironments that not only support neoplastic growth and metastasis, but also significantly reduce the effectiveness and corrupt the functions of both the innate and adaptive arms of anti-cancer immunity [10]. Among the immunosuppressive components of tumor microenvironments are various soluble factors such as IL-10, TGF- $\beta$, vascular endothelial growth factor (VEGF), prostaglandin E2 $\left(\mathrm{PGE}_{2}\right), \mathrm{HMGB} 1$, indoleamine2,3-dioxygenase (IDO), as well as soluble forms of phosphatidylserine, Fas receptors, and MHC class I-related chain A proteins (reviewed in $[117,118]$ ). Another recently recognized immunosuppressive mechanism involves the activation of the so-called immune checkpoints whose function is to prevent overstimulation of the immune system (reviewed in $[119,120])$. The two most important immune checkpoint co-inhibitory molecules likely to play a role in induction and maintenance of the immunosuppressive state within tumors are members of the immunoglobulin gene superfamily, the cytotoxic $\mathrm{T}$ lymphocyte-associated antigen 4 (CTLA-4) whose expression on $\mathrm{T}$ helper cells suppresses the activity of cytolytic $\mathrm{CD}^{+} \mathrm{T}$ lymphocytes, and the programmed death 1 (PD-1; CD279) receptor primarily expressed on tumor-infiltrating lymphocytes (TILs) and monocytes which, upon combining with its respective ligands (PDL-1 and PDL-2), negatively regulates the anti-neoplastic function of $\mathrm{T}$ cells $[121,122]$; in addition, the PD-1:PDL-1 interaction may promote the development and function of regulatory $\mathrm{T}$ (Treg) cells [123].

Active immunosuppression is also exerted by many non-specific and specific cellular effectors residing in or attracted to neoplastic tissue. Many different cells capable of inhibiting anti-cancer immunity and promoting cancer growth have now been identified. These include Treg lymphocytes [125, 126], MDSCs [127-130], macrophages [128, 131-133], natural killer T (NKT) [134-136], Th17 [137-139] and B lymphocytes [140-143], but also neutrophils [131, 144-147], dendritic cells (DCs) [148-151], mast cells (MCs) [152], and mesenchymal stem cells [153-155].

It has been finally well established that persistent activation of pro-inflammatory immunity facilitates cellular transformation and promotes tumor advancement. Unlike acute transient inflammatory responses which attract and activate elements of the innate immune system, chronic inflammation not only supports cancer progression, but also prevents the host from mounting effective immune defenses against it [129, 156-162]. An intermediate role in this process of the inflammation-driven type 2 immune response is played by MDSCs which are attracted to inflammatory sites and facilitate tumor growth $[163,164]$. Chronic inflammation, as a powerful driver of carcinogenesis, is associated with aberrant signaling mediated by the nucleotide-binding oligomerization domain (NOD)-like receptors expressed on DCs, macrophages, and lymphocytes [165, 166]. Critical immunosuppressive mechanisms operating in the tumor microenvironment during the advanced stages of carcinogenesis are outlined in Fig. 1.

\section{Anti-neoplastic and immunomodulatory effects of LLR}

\section{Overview}

The development and progression of cancer in both humans and laboratory animals can be suppressed or prevented by exposures to LLR. The results of about 40 epidemiological studies published since 1987 have demonstrated decreased or unaltered cancer incidence or mortality rates in human populations exposed to LLR during medical diagnostic tests and therapy, in the course of professional activities, or as residents of geographical areas and homes with elevated levels of natural background radiation (evidence presented in Supplementary Table 1). Likewise, between 1996 and 2014, at least 27 reports were published from controlled experiments carried out in mice, rats, and dogs, as well as in cultured cells demonstrating that single, multiple, or chronic irradiations with LLR exert anti-neoplastic 
Fig. 1 Tumor microenvironment during the late stages of cancer development: Immunosuppressive influences. $B$ B lymphocytes, $C D 8^{+} \mathrm{CD}^{+}$ T lymphocytes, $H M G B 1$ high-mobility group box 1 protein, IDO indoleamine2,3-dioxygenase, $M 1$ phenotype 1 macrophages, $M 2$ phenotype 2 macrophages, $N 1$ phenotype 1 neutrophils, $N 2$ phenotype 2 neutrophils, Treg regulatory $\mathrm{T}$ lymphocytes, $N K G 2 D L$ ligand for the natural killer group 2D receptor, $N K G 2 D$ natural killer group $2 \mathrm{D}$ receptor, $V E G F$ vascular endothelial growth factor

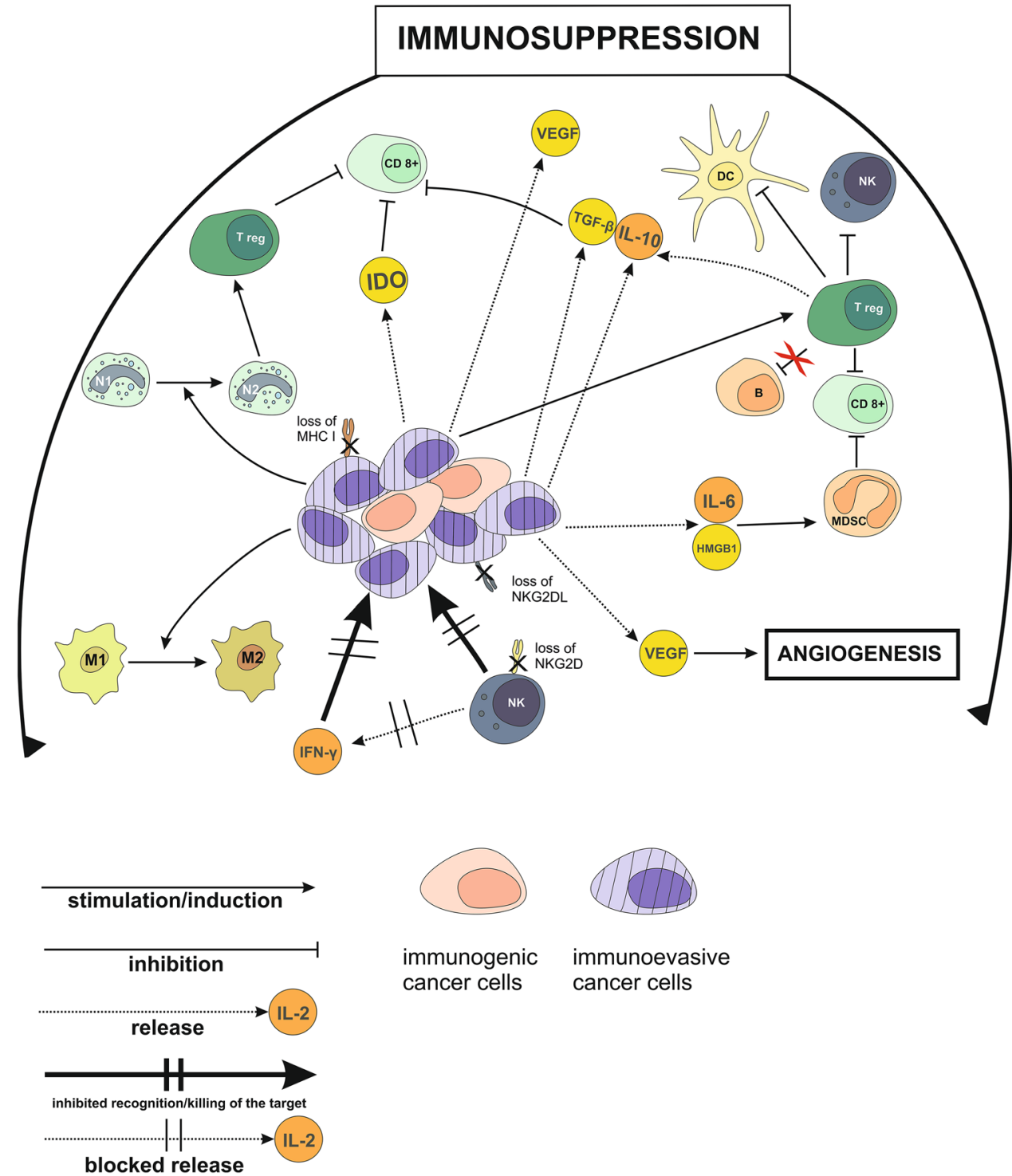

activities and markedly inhibit the growth and/or advancement of spontaneous or induced tumors (evidence presented in Supplementary Table 2). In general, the results of both epidemiological and experimental studies indicate or suggest that, in the case of short-term exposures at a high-dose rate, the upper threshold for the control of tumor growth is around 0.1 Gy [25, 61-63, 71, 167-169]. As evidenced by the results of experimental studies conducted in the in vivo and in vitro systems, one of the most important underlying mechanisms of such tumor-inhibitory effects is up-regulation of both the innate and adaptive immunity. Numerous reports published between 1988 and 2014 indicate that exposures to LLR are potent stimulators of various anti-neoplastic functions of the immune system, including inhibition of inflammation and/or up-regulation of anti-inflammatory cytokines (evidence presented in Supplementary Table 3 and reviewed in [74, 80, 94, 170, 171]).

\section{Specific studies demonstrating anti-tumor effects} by LLR

There are also a number of reports dating back to early 1980s which demonstrate association of the LLR-induced up-regulation of anti-neoplastic immunity with inhibition of cancer development:

1. In 1982, Robert Anderson and collaborators [172] were among the first to report retardation of the growth of transplanted tumors in A/J mice following WBI with $\mathrm{X}$-rays at doses ranging from 0.005 to $0.025 \mathrm{~Gy}$ immediately prior to s.c. inoculation of Sarcoma I cells. The evidence clearly suggested the involvement of "a very radiosensitive T cell with suppressor activity".

2. In 1994, Kharazi et al. showed that chronic low-dose WBI with $\gamma$-rays (0.04 Gy per exposure, three times per 
week for 4 weeks) when combined with caloric restriction enhanced the regression of mammary tumors spontaneously developing in female $\mathrm{C} 3 \mathrm{H} / \mathrm{He}$ mice. These tumors were massively infiltrated with cytotoxic $\mathrm{CD}^{+}{ }^{+} \mathrm{T}$ cells. Such tumor regression did not occur in mice subjected to caloric restriction alone [173].

3. As reported in 1999 by Hashimoto et al., a single WBI at 0.2 Gy of $\gamma$-rays of WKHA rats injected with hepatoma cells led to a significant reduction in the number of lung and lymph node metastases accompanied by the markedly stimulated influx of $\mathrm{CD} 8^{+}$ lymphocytes into the spleen and the tumor site along with the enhanced expression of mRNAs for IFN- $\gamma$ and TNF- $\alpha$ and down-regulation of mRNA for TGF$\beta$; no mRNAs for IL-4, IL-6, and IL-10, the Th2-type cytokines that inhibit the anti-tumor Th1 responses, were detected in these tissues [69].

4. The studies by Yu et al. showed that a single exposure of male Kunming mice (a strain similar to C57BL/6 mice) to $0.075 \mathrm{~Gy} \mathrm{X}$-rays $6 \mathrm{~h}$ before implantation of S180 sarcoma cells significantly inhibited tumor growth accompanied by the influx of TILs as well as enhanced necrosis and down-regulation of the expression of receptors for VEGF in the neoplastic tissue [73, 74].

5. Continuous irradiation of C57BL/6 mice with $\gamma$-rays at $1.2 \mathrm{mGy} / \mathrm{h}$ for 258 days (up to $7.2 \mathrm{~Gy}$ total dose) did not induce thymic lymphomas, whereas the same total dose absorbed during four acute exposures to X-rays at 1.8 Gy resulted in the appearance of the lymphomas in $90 \%$ of these animals; in the continuously irradiated mice, the numbers of $\mathrm{CD} 4^{+} \mathrm{T}$ cells and antibodyproducing $\mathrm{B}$ cells were significantly enhanced in the spleen [75].

6. Continuous exposure to $\gamma$-rays of the lymphoma-prone $\mathrm{SJL} / \mathrm{J}$ mice at $100 \mathrm{mGy} / \mathrm{y}$ dose rate slightly prolonged life span of the animals and the effect was accompanied by the significant increase in the percentages of $\mathrm{CD} 49^{+} \mathrm{NK}$ cells and decreased percentages of $\mathrm{CD} 4^{+}$ and $\mathrm{CD}^{+}$lymphocytes in the spleen [174]. When spleens of rats with a diethylnitrosamine-induced liver cancer were irradiated at 0.15 Gy from the $6 \mathrm{MeV}$ $\beta$-beam accelerator at $100 \mathrm{mGy} / \mathrm{min}$ dose rate, the percentage of $\mathrm{CD} 4{ }^{+} \mathrm{CD} 25^{+}$Treg cells in the blood significantly decreased and the levels of Foxp3, IL-10, TGF$\beta$, and CTLA- 4 were down-regulated in the spleen and the tumor; these changes were accompanied by the suppressed tumor growth [175].

7. Experimental combinations of low-level WBI with the conventional (intermediate- or high-dose) local RT also yielded promising results: using murine tumor models of B16 melanoma and Lewis lung carcinoma, Liu and collaborators demonstrated that when fractionated local X-ray irradiations of the tumors at $2 \mathrm{~Gy} /$ fraction were several times substituted for WBI at $0.075 \mathrm{~Gy}$, the cancer control (as judged by the reduced tumor mass and pulmonary metastases as well as by the increased survival of the hosts) was significantly improved compared to local RT alone; this effect was accompanied by up-regulation of the activities of the splenic NK and cytotoxic $\mathrm{T}$ lymphocytes which secreted elevated amounts of IFN- $\gamma$ and TNF- $\alpha[77,78]$.

\section{Our strategies showing anti-tumor effects by LLR}

In a series of our own experiments carried out in the relatively radiosensitive $\mathrm{BALB} / \mathrm{c}$ mice and the relatively radioresistant C57BL/6 mice, both single and multiple WBI with X-rays at total doses ranging from 0.05 to $0.2 \mathrm{~Gy}$ reproducibly suppressed development of the induced neoplastic colonies in the lungs. Since the mice were wholebody irradiated before inoculation of the syngeneic tumor cells, the obvious suggestion was that the low-level X-ray exposures stimulated systemic innate anti-neoplastic reactions. Although we were not able to directly estimate the activities of immune cells in the lungs, a significant stimulation of the cytotoxic activities of NK cells and LPS- and IFN- $\gamma$-stimulated macrophages obtained from the spleen and peritoneal cavity, respectively, was detected in the $\mathrm{X}$-ray-exposed mice from both strains. Interestingly, no elevation of the activities of these cells was detected after their in vitro irradiation at the same doses of $\mathrm{X}$-rays indicating that enhancing of the NK- and macrophage-mediated cytolytic functions by LLR depends on the presence of factors occurring in in vivo but not the in vitro conditions [81-90, 176-179].

\section{Clinical trials}

The above-described epidemiological and experimental observations of anti-neoplastic and immunomodulatory effects of LLR exposures provide grounds for clinical trials with WBI or HBI of oncological patients [101, 180]. Even before the aforementioned evidence gained significance, a few LLR-based therapy trials had been performed. In 1965, Holder reported on positive therapeutic effects of the lowlevel total-body irradiation of patients with multiple myeloma [181]. In 1975, Kazem described curative effects of WBI $(0.15$ Gy of $\gamma$-rays daily for the first 5 days and thereafter at $0.1-0.15$ Gy every other day or at longer intervals to the total doses of 2.0-2.65 Gy applied over 5-12 weeks) of patients with disseminated stage III lymphomas [182]. Likewise, Chaffey et al. obtained complete remissions in 32 out of 40 patients with advanced lymphocytic lymphoma 
after repeated WBI $(0.15$ Gy twice a week to a total dose of $1.5 \mathrm{~Gy}$ ) as an initial and only primary therapy [102]. Very promising results of low-level total-body exposures to $\gamma$-rays of patients with non-Hodgkin's lymphoma (NHL) were also reported by Qasim [183] and Choi et al. [103]. In one of the later trials, 24 out of 26 patients with stage IV low grade NHL were in complete remission after two courses of low-dose, total-body irradiation at $0.75 \mathrm{~Gy}$ given in five fractions; when the initially pathological lymph node areas of these patients were 1 month later treated with the conventional RT (total dose of 40 Gy applied in 20 fractions), the disease remitted in yet another patient [184]. Similarly, Safwat et al. who used low-level total-body exposures $(0.1-0.25$ Gy several times a week to the total dose of 1.5-2.0 Gy) obtained complete remissions in 11 out of 35 patients and 2-year progression-free survival in 12 patients with relapsed and/or chemo-resistant NHL; in 14 patients, a significant increase in the percentage of $\mathrm{CD}^{+} \mathrm{T}$ cells in the blood was noted [105]. In addition, as demonstrated by Sakamoto et al., low-dose HBI with X-rays (0.1-0.15 Gy two times a week for 5 weeks) combined with local RT ( 2 Gy five times a week for 6 weeks) resulted in the 5-year survival of $84 \%$ of patients with stage I and II NHL as compared to $65 \%$ survival of patients treated solely with local RT (the difference significant at $p<0.05$ ); in these patients, percentages of peripheral blood $\mathrm{CD}^{+}{ }^{+} \mathrm{T}$ helper lymphocytes were significantly elevated [100].

While more clinical trials employing WBI or HBI with LLR are needed, they are hampered by radiation safety regulations based on the linear, no threshold (LNT) model of the dose-effect relationship assuming that any absorbed dose of radiation causes a finite increase in cancer risk. There is a growing consensus that the LNT hypothesis lacks a solid experimental foundation and is based largely on ideology rather than science [25, 169, 185-193]. Hopefully, the many recent appeals from radiobiologists, physicians, and health physicists to various regulatory bodies and authorities to base the radiation protection system on scientific data indicating that there are quantitative and qualitative differences between the effects of low doses delivered at low dose rates and high doses delivered at high-dose rates [171, 187, 188, 190, 192, 194, 195] will lead to a revision of current radiation protection regulations, so that WBI with LLR can be tested in clinical trials.

\section{Suggested effects of LLR on cancer immunoediting process}

As reviewed above, both acute and chronic exposures to LLR stimulate various anti-neoplastic immune reactions that are stifled or corrupted within the tumor microenvironment, especially during the later stages of carcinogenesis.
Based on evidence indicating that tumor-inhibiting effects of LLR have been observed in both humans and experimental animals exposed in many different ways to single, multiple, and chronic irradiation with LLR, it may be argued that many, if not all, of the above-reviewed tumorpromoting immune mechanisms are likely to be blocked and/or reversed by such exposures (Fig. 2). Indeed, data indicating that LLR exposures may reverse the tumor-associated immune suppression has recently begun to emerge, even though many underlying LLR-induced mechanisms remain to be clarified. Based on the current evidence it may be postulated that, in addition to the direct activation of NK lymphocytes [83, 196, 197] and possibly other antitumor cytotoxic cells, LLR exposures enhance the "visibility" and/or susceptibility of cancer cells to immune assaults through stimulation of the expression by neoplastic and immune cells of molecules and ligands (e.g., CD2, B7, $\mathrm{CD} 28, \mathrm{NKG} 2 \mathrm{D})$ necessary for triggering of cytotoxic reactions [198-200] and/or turning on "danger signals" in the neoplastic tissue [201, 202]. Furthermore, low-level radiation exposures are likely to alleviate or reverse the tumorassociated immune degeneracy through elimination or inhibition of the multiple cells, cytokines, and other factors associated with immunosuppressive loops induced by the tumor [175, 203-207]. This could result in: (a) shifting of the immune response in favor of the anti-neoplastic phenotypes such as Th1 in the case of $\mathrm{CD}^{+} \mathrm{T}$ cells $[97,208]$, M1 in the case of macrophages [209, 210], and N1 in the case of neutrophils [211], (b) targeting the Treg-Th17 and Th17DC interactions conducive to tumor regression [212-214], (c) activation of the Toll-like receptor-mediated signaling in phagocytes and antigen-presenting cells [215-217], (d) attenuation of the chronic inflammation pertinent to cancer initiation, promotion, and progression [94, 95, 170, 218, 219], and/or (e) down-regulation of the immune checkpoint molecules such as the CTLA-4, PD-1, and/or PD-L1 on $T$ cells [198, 220-222]. Indeed, one of the recent reports indicates that hypofractionated $\gamma$-ray irradiation of tumors induced in C57BL/6 mice combined with blockade of the PD-1 checkpoint stimulated accumulation of TILs associated with complete eradication of very large neoplasms [222]. In addition, there are numerous non-immune mechanisms triggered by LLR that positively affect normal, but not malignant cells [29]. These include: (a) increased cell proliferation, (b) stimulation of anti-oxidant reactions associated with the reduction of tissue injury, (c) improved repair of the DNA damage, and (d) metabolic shift from oxidative phosphorylation to aerobic glycolysis resulting in increased radioresistance of healthy tissues. Such outcomes are of primary importance for the combination of the LLRbased immunotherapy with classic forms of cancer therapy (i.e., high-dose RT and chemotherapy) that are lethal to normal cells and tissues and promote the formation of 
Fig. 2 LLR-induced immunerelated mechanisms mediating anti-neoplastic effects: Proposed framework. $A D C C$ antibody-dependent cellular cytotoxicity, $B$ B lymphocytes, $C D 8^{+} \mathrm{CD} 8^{+} \mathrm{T}$ lymphocytes, $D A M P s$ damage-associated molecular pattern molecules, $H M G B 1$ high-mobility group box 1 protein, $M 1$ phenotype 1 macrophages, $M 2$ phenotype 2 macrophages, $N 1$ phenotype 1 neutrophils, $N 2$ phenotype 2 neutrophils, Treg regulatory $\mathrm{T}$ lymphocytes, $N K G 2 D L$ ligand for the natural killer group 2D receptor, $N K G 2 D$ natural killer group $2 \mathrm{D}$ receptor, $V E G F$ vascular endothelial growth factor

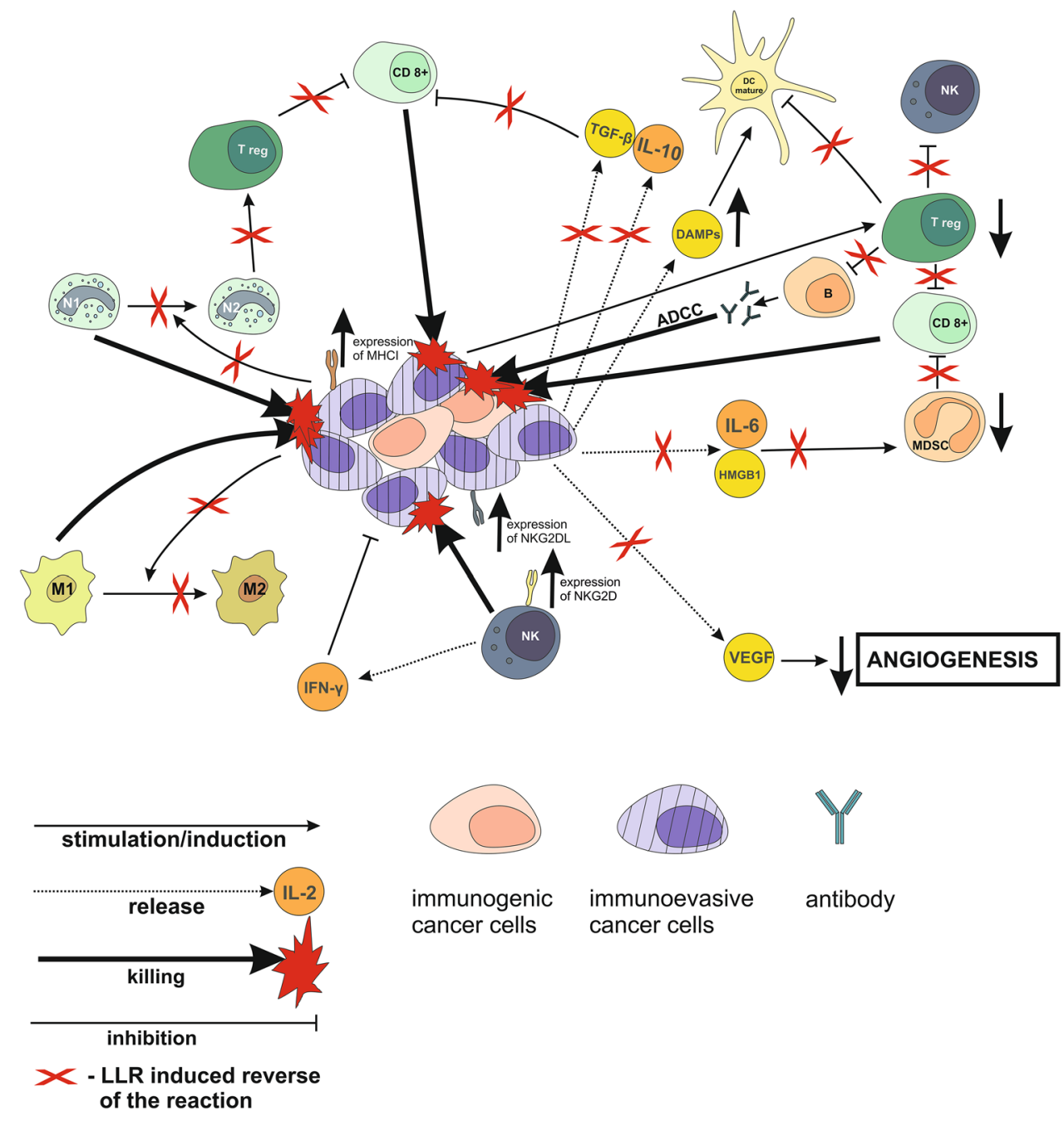

reactive oxygen species and inflammation. It is expected that other LLR-triggered reactions and mechanisms will be detected providing additional grounds for the use of the truly low-level exposures to IR in the treatment of cancer and, possibly, other diseases.

\section{Conclusion and prospects}

Cancer immunotherapy has matured from the application of several therapeutic agents, including tumor cell- and dendritic cell-based vaccines, anti-cytokine antibodies, checkpoint inhibitors, and genetically engineered $\mathrm{T}$ cells and stem cells, which collectively act to reverse immune suppression in the tumor environment and/or immune resistance of tumor cells (reviewed in [208]). There are also clinical trials combining such agents with local irradiation of tumors at moderate doses (i.e., >0.5-1.0 Gy per fraction) currently used in RT [16]. The recently acknowledged capacity of locally applied moderate or high (radiotherapeutic) doses of radiation to induce immunogenic death of cancer cells and local inflammatory reactions associated with stimulation of dendritic cells and enhancing the suppressed anti-cancer immunity has been employed as an adjuvant to improve the efficacy of existing immunotherapy protocols (reviewed in [11-19, 21]). However, such exposures can also cause persistent inflammation and multiple cell death in normal tissues, impede various immune and other physiological functions, and increase the risk of secondary primary cancers. In contrast, LLR exposures do not kill or impair and actually support functions of normal cells and tissues, selectively eliminate precancerous and transformed cells, attenuate rather than induce chronic inflammation, stimulate various anti-neoplastic reactions of the immune system, and are not associated with the development of secondary malignancies [21, 29, 94, 95, 170]. Finally, as indicated by the above-reviewed results of experimental and epidemiological studies as well as several clinical trials, WBI or HBI with LLR are not likely to induce any 
untoward side effects and can thus be used in treatment of patients with systemic or metastatic cancer.

It is, therefore, time to employ whole- or half-body exposures to LLR (alone or as an adjuvant to conventional therapeutics) to restore the efficacy of systemic anti-cancer functions of the immune system, the most potent guardian against neoplasia. This approach is expected to mediate improved clinical responses in cancer patients, as well as protect normal tissues from the well-known adverse effects associated with standard chemo- and radiotherapy used in contemporary cancer therapeutics.

\section{Compliance with ethical standards}

Conflict of interest The authors declare that they have no conflict of interest.

Open Access This article is distributed under the terms of the Creative Commons Attribution 4.0 International License (http:// creativecommons.org/licenses/by/4.0/), which permits unrestricted use, distribution, and reproduction in any medium, provided you give appropriate credit to the original author(s) and the source, provide a link to the Creative Commons license, and indicate if changes were made.

\section{References}

1. Corthay A (2014) Does the immune system naturally protect against cancer? Front Immunol 5:197. doi:10.3389/ fimmu.2014.00197

2. Burnet M (1957) Cancer: a biological approach III viruses associated with neoplastic conditions IV practical applications. $\mathrm{Br}$ Med J 1:841-847. doi:10.1136/bmj.1.5023.841

3. Thomas L (1959) Discussion in: Lawrence HS (ed) Cellular and humoral aspects of the hypersensitive states. Hoeber-Harper, New York, pp 529-532

4. Dunn GP, Bruce AT, Ikeda H, Old LJ, Schreiber RD (2002) Cancer immunoediting: from immunosurveillance to tumour escape. Nat Immunol 3:991-998. doi:10.1038/ni1102-991

5. Dunn GP, Old LJ, Schreiber RD (2004) The immunobiology of cancer immunosureveillance and immunoediting. Immunity 21:137-148. doi:10.1016/j.immuni.2004.07.017

6. Dunn GP, Old LJ, Schreiber RD (2004) The three Es of cancer immunoediting. Annu Rev Immunol 22:329-360. doi:10.1146/ annurev.immunol.22.012703.104803

7. Schreiber RD, Old LJ, Smyth MJ (2011) Cancer immunoediting: integrating immunity's roles in cancer suppression and promotion. Science 331:1565-1570. doi:10.1126/science.1203486

8. Hanahan D, Coussens LM (2012) Accessories to the crime: functions of cells recruited to the tumour microenvironment. Cancer Cell 21:309-322. doi:10.1016/j.ccr.2012.02.022

9. Barcellos-Hoff MH, Lyden D, Wang TC (2013) The evolution of the cancer niche during multistage carcinogenesis. Nat Rev Cancer 13:511-518. doi:10.1038/nrc3536

10. Yaguchi T, Kawakami Y (2016) Cancer-induced heterogeneous immunosuppressive tumor microenvironments and their personalized modulation. Int Immunol 28:393-399. doi:10.1093/ intimm/dxw030

11. Rödel F, Frey B, Gaipl U, Keilholz L, Fournier C, Manda K et al (2012) Modulation of inflammatory immune reactions by low-dose ionizing radiation: Molecular mechanisms and clinical applications. Curr Medic Chem 19:1741-1750. doi:10.2174/092986712800099866

12. Burnette B, Fu YX, Weichselbaum RR (2012) The confluence of radiotherapy and immunotherapy. Front Oncol 2:143. doi:10.3389/fonc. 2012.00143

13. Kaur P, Asea A (2012) Radiation-induced effects and the immune system in cancer. Front Oncol. doi:10.3389/ fonc.2012.00191

14. Formenti SC, Demaria S (2013) Combining radiotherapy and cancer immunotherapy: a paradigm shift. J Natl Cancer Inst 105:256-265. doi:10.1093/jnci/djs629

15. Demaria S, Pilones KA, Vanpouille-Box C, Golden EB, Formenti SC (2014) The optimal partnership of radiation and immunotherapy: from preclinical studies to clinical translation. Radiat Res 182:170-181. doi:10.1667/RR13500.1

16. Draghiciu O, Walczak M, Hoogeboom BN, Franken KL, Melief KJ, Nijman HW, Daemen T (2014) Therapeutic immunization and local low-dose tumour irradiation, a reinforcing combination. Int J Cancer 134:859-872. doi:10.1002/ijc.28418

17. Frey B, Rubner Y, Kulzer L, Werthmöller N, Weiss EM, Fietkau R, Gaipl US (2014) Antitumour immune responses induced by ionizing irradiation and further immune stimulation. Cancer Immunol Immunother 63:29-36. doi:10.1007/ s00262-013-1474-y

18. Wattenberg MM, Fahim A, Ahmed MM, Hodge JW (2014) Unlocking the combination: potentiation of radiation-induced antitumour responses with immunotherapy. Radiat Res 182:126-138. doi:10.1667/RR13374.1

19. Golden EB, Apetoh L (2015) Radiotherapy and immunogenic cell death. Semin Radiat Oncol 25:11-17. doi:10.1016/j. semradonc.2014.07.005

20. Kumari A, Simon SS, Moody TD, Garnett-Benson C (2016) Immunomodulatory effects of radiation; what is next for cancer therapy? Future Oncol 12:239-256. doi:10.2217/fon.15.300

21. Tubiana M (2009) Can we reduce the incidence of second primary malignancies occurring after radiotherapy? A critical review. Radiother Oncol 91:4-15. doi:10.1016/j. radonc.2008.12.016

22. Gudowska I, Ardenfors O, Toma-Dasu I, Dasu A (2014) Radiation burden from secondary doses to patients undergoing radiation therapy with photons and light ions and radiation doses from imaging modalities. Radiat Prot Dosim 161:357-362. doi:10.1093/rpd/nct335

23. Ng J, Shuryak I (2015) Minimizing second cancer risk following radiotherapy: current perspectives. Cancer Manag Res 7:111. doi:10.2147/CMAR.S47220

24. Albrecht H, Durbin-Johnson B, Yunis R, Kalanetra KM, Wu S, Chen $R$ et al (2012) Transcriptional response of ex vivo human skin to ionizing radiation: comparison between low- and highdose effects. Radiat Res 177:69-83. doi:10.1667/RR2524.1

25. Feinendegen LE, Pollycove M, Neumann RD (2013) Hormesis by low dose radiation effects: Low-dose cancer risk modeling must recognize up-regulation of protection In: Baum RP (ed) Therapeutic nuclear medicine. Springer, Berlin, pp 789-805 doi:10.1007/174_2012_686

26. Yu H, Liu N, Wang H, Shang Q, Jiang P, Zhang Y (2013) Different responses of tumor and normal cells to low-dose radiation. Contemp Oncol (Pozn) 17:356-362. doi:10.5114/ wo.2013.35289

27. Brooks AL, Dauer LT (2014) Advances in radiation biology: effect on nuclear medicine. Semin Nucl Med 44:179-186. doi:10.1053/j.semnuclmed.2014.03.004

28. Wodarz D, Sorace R, Komarova NL (2014) Dynamics of cellular responses to radiation. PLoS Comput Biol 2014 10:e1003513. doi:10.1371/journal.pcbi.1003513 
29. Yang G, Li W, Jiang H, Liang X, Zhao Y, Yu D et al (2016) Low-dose radiation may be a novel approach to enhance the effectiveness of cancer therapeutics. Int J Cancer 139:21572168. doi:10.1002/ijc.30235

30. Rowland RE (1970) Dose and damage in long term radium cases. In Cloutier RJ, Edwards CL, Snyder WS (eds), Medical radionuclides: radiation dose and effects: Proceedings of a Symposium held at the Oak Ridge Associated Universities, Dec 8-11, 1969. Publ.: US Atomic Energy Comission, Division of Technical Information (available from Clearinghouse for Federal Scientific and Technical Information, Springfield, VA), pp 369-386

31. Nambi KS, Soman SD (1987) Environmental radiation and cancer in India. Health Phys 52:653-657. doi:10.1097/00004032-198705000-00018

32. Nambi KS, Soman SD (1990) Further observations on environmental radiation and cancer in India. Health Phys 59:339-344

33. Wei LX, Zha YR, Tao ZF, He WH, Chen DQ, Yuan YL (1990) Epidemiological investigation of radiological effects in high background radiation areas of Yangjiang, China. J Radiat Res 31:119-136. doi:10.1269/jrr.31.119

34. Mifune M, Sobue $\mathrm{T}$, Arimoto $\mathrm{H}$, Komoto $\mathrm{Y}$, Kondo $\mathrm{S}$, Tanooka H (1992) Cancer mortality survey in a spa area (Misasa, Japan) with a high radon background. Jpn J Cancer Res 83:1-5. doi:10.1111/j.1349-7006.1992.tb02342.x

35. Ye W, Sobue T, Lee VS, Tanooka H, Mifune M, Suyama A et al (1998) Mortality and cancer incidence in Misasa, Japan, a spa area with elevated radon levels. Jpn J Cancer Res 89:789-796. doi:10.1111/j.1349-7006.1998.tb00630.x

36. Nair RR, Rajan B, Akiba S, Jayalekshmi P, Nair MK, Gangadharan P et al (2009) Background radiation and cancer incidence in Kerala, India-Karanagappally cohort study. Health Phys 96:55-66. doi:10.1097/01.HP.0000327646.54923.11

37. Fornalski KW, Dobrzyński L (2012) The cancer mortality in high natural radiation areas in Poland. Dose Response 10:541-561. doi:10.2203/dose-response.11-035.Fornalski

38. Aliyu AS, Ramli AT (2015) The world's high background natural radiation areas (HBNRAs) revisited: A broad overview of the dosimetric, epidemiological and radiobiological issues. Radiat Meas 73:51-59. doi:10.1016/j.radmeas.2015.01.007

39. Cohen BL (1989) Expected indoor 222Rn levels in counties with very high and very low lung cancer rates. Health Phys 57:897-907. doi:10.1097/00004032-198912000-00004

40. Cohen BL (1995) Test of the linear-no threshold theory of radiation carcinogenesis for inhaled radon decay products. Health Phys 68:157-174. doi:10.1097/00004032-199502000-00002

41. Cohen BL (1997) Lung cancer rate vs mean radon level in US counties of various characteristics. Health Phys 72:114-119. doi:10.1097/00004032-199701000-00016

42. Cohen BL (2008) The linear no-threshold theory of radiation carcinogenesis should be rejected. JPandS 13:70-76

43. Becker K (2003) Health effects of high radon environments in central. Europe: Another test for the LNT hypothesis? Nonlinearity Biol Toxicol Med 1:3-35. doi:10.1080/15401420390844447

44. Miller AB, Howe GR, Sherman GJ, Lindsay JP, Yaffe MJ, Dinner PJ et al (1989) Mortality from breast cancer after irradiation during fluoroscopic examinations in patients being treated for tuberculosis. New Eng J Med 321:1285-1289. doi:10.1056/ NEJM198911093211902

45. Kostyuchenko VA, Krestinina LYu (1994) Long-term irradiation effects in the population evacuated from the EastUrals radioactive trace area. Sci Total Environ 142:119-125. doi:10.1016/0048-9697(94)90080-9
46. Doody MM, Mandel JS, Lubin JH, Boice JD Jr (1998) Mortality among United States radiologic technologists, 1926-90. Cancer Causes Control 9:67-75. doi:10.1023/A:1008801404245

47. Berrington A, Darby SC, Weiss HA, Doll R (2001) 100 years of observation on British radiologists: mortality from cancer and other causes 1897-1997. Br J Radiol 74:507-519. doi:10.1259/ bjr.74.882.740507

48. Mohan AK, Hauptmann M, Freedman DM, Ron E, Matanoski GM, Lubin JH et al (2003) Cancer and other causes of mortality among radiologic technologists in the United States. Int J Cancer 103:259-267. doi:10.1002/ijc.10811

49. Omar RZ, Barber JA, Snith PG (1999) Cancer mortality and morbidity among plutonium workers at the Sellafield plant of British nuclear fuels. Br J Cancer 79:1288-1301. doi:10.1038/ sj.bjc. 6690207

50. McGeoghegan D, Binks K (2000) The mortality and cancer morbidity experience of workers at the Capenhurst uranium enrichment facility 1946-95. J Radiol Prot 20:381-401. doi:10.1088/0952-4746/20/4/303

51. Boice JD Jr, Bigbee WL, Mumma MT, Blot WJ (2003) Cancer mortality in counties near two former nuclear materials processing facilities in Pennsylvania, 1950-1995. Health Phys 85:691700. doi:10.1097/00004032-200312000-00014

52. Atkinson WD, Law DV, Bromley KJ, Inskip HM (2004) Mortality of employees of the United Kingdom Atomic Energy Authority, 1946-1997. Occup Environ Med 61:577-585. doi:10.1136/oem.2003.012443

53. Sponsler R, Cameron JR (2005) Nuclear shipyard worker study (1980-1988): a large cohort exposed to low-dose-rate gamma radiation. Int $\mathbf{J}$ Low Radiat 1:463-478. doi:10.1504/ IJLR.2005.007915

54. Boice JD Jr, Mumma MT, Blot WJ (2006) Cancer mortality among populations residing in counties near the Hanford site, 1950-2000. Health Phys 90:431-445. doi:10.1097/01. HP.0000183762.47244.bb

55. Hwang SL, Guo HR, Hsieh WA, Hwang JS, Lee SD, Tang JL et al (2006) Cancer risks in a population with prolonged low dose-rate $\mathrm{\gamma}$-radiation exposure in radiocontaminated buildings, 1983-2002. Int J Radiat Biol 82:849-858. doi:10.1080/09553000601085980

56. Boice JD Jr, Mumma MT, Blot WJ (2007) Cancer and noncancer mortality in populations living near uranium and vanadium mining and milling operations in Montrose County, Colorado, 1950-2000. Radiat Res 167:711-726. doi:10.1667/RR0839.1

57. Cardis E, Vrijheid M, Blettner M, Gilbert E, Hakama M, Hill $\mathrm{C}$ et al (2007) The 15-Country collaborative study of cancer risk among radiation workers in the nuclear industry: estimates of radiation-related cancer risks. Radiat Res 167:396-416. doi:10.1667/RR0553.1

58. Minister of Public Works and Government Services Canada, Canadian Nuclear Safety Commission (CNSC) (2011) Verifying Canadian nuclear energy worker radiation risk: A reanalysis of cancer mortality in Canadian nuclear energy workers (19571994) Summary report (2011). ISBN 978-1-100-17760-1

59. Thompson RE, Nelson DF, Popkin JH, Popkin Z (2008) Casecontrol study of lung cancer from residential radon exposure in Worcester county, Massachusetts. Health Phys 94:228-241. doi:10.1097/01.HP.0000288561.53790.5f

60. Thompson RE (2010) Epidemiological evidence for possible radiation hormesis from radon exposure: a case-control study conducted in Worcester, MA. Dose Response 9:59-75. doi:10.2203/dose-response.10-026.Thompson

61. UNSCEAR (2008) Report (2011): Sources and Effects of Ionizing Radiation United Nations Scientific Committee on the Effects of Atomic Radiation Vol II: Effects, Scientific Annex D, United Nations, New York, pp 45-219 
62. Jaworowski Z (2010) Observations on the Chernobyl disaster and LNT. Dose Response 8:148-171. doi:10.2203/doseresponse.09-029.Jaworowski

63. Ivanov VK, Tsyb AF (2013) Thyroid cancer: lessons of Chernobyl and prognosis for Fukushima. Vestn Ross Akad Med Nauk (5):38-44.

64. Jargin SV (2014) Chernobyl-related cancer and precancerous lesions: incidence increase vs late diagnostics. Dose Response 12:404-415. doi:10.1504/IJLR.2006.012017

65. Tubiana M, Diallo I, Chavaudra J, Lefkopoulos D, Bourhis J, Girinsky T et al (2011) A new method of assessing the dosecarcinogenic effect relationship in patients exposed to ionizing radiation A concise presentation of preliminary data. Health Phys 100:296-299. doi:10.1097/HP.0b013e31820a1b35

66. Lehrer S, Rosenzweig KE (2015) Lung cancer hormesis in high impact States where nuclear testing occurred. Clin Lung Cancer 16:152-155. doi:10.1016/j.cllc.2014.09.010

67. Bhattacharjee D (1996) Role of radioadaptation on radiationinduced thymic lymphoma in mice. Mutat Res 358:231-235. doi:10.1016/S0027-5107(96)00125-X

68. Hashimoto S (1997) Effects of low-dose total body irradiation (TBI) on tumor-bearing rats. Nihon Igaku Hoshasen Gakkai Zasshi 57:418-424

69. Hashimoto S, Shirato H, Hosokawa M, Nishioka T, Kuramitsu Y, Matushita K et al (1999) The suppression of metastases and the change in host immune response after low-dose total-body irradiation in tumour-bearing rats. Radiat Res 151:717-724. doi:10.1016/S0360-3016(98)80333-7

70. Mitchel RE, Jackson JS, McCann RA, Boreham DR (1999) The adaptive response modifies latency for radiation-induced myeloid leukemia in CBA/H mice. Radiat Res 152:273-279. doi: $10.2307 / 3580327$

71. Mitchel RE, Jackson JS, Morrison DP, Carlisle SM (2003) Low doses of radiation increase the latency of spontaneous lymphomas and spinal osteosarcomas in cancer-prone, radiation-sensitive Trp53 heterozygous mice. Radiat Res 159:320 327. doi:10.1667/0033-7587(2003)159[0320:LDORIT]2.0 $\mathrm{CO} ; 2$

72. Redpath JL, Lu Q, Lao X, Molloi S, Elmore E (2003) Low doses of diagnostic energy $\mathrm{X}$-rays protect against neoplastic transformation in vitro. Int J Radiat Biol 79:235-240. doi:10.1080/0955300031000096306

73. Yu HS, Song AQ, Lu YD, Qiu WS, Shen FZ (2004) Effects of low-dose radiation on tumour growth, erythrocyte immune function and SOD activity in tumour-bearing mice. Chin Med J (Engl) 117:1036-1039

74. Yu HS, Liu ZM, Yu XY, Song AQ, Liu N, Wang H (2013) Low-dose radiation induces antitumour effects and erythrocyte system hormesis. Asian Pac J Cancer Prev 14:4121-4126. doi:10.7314/APJCP.2013.14.7.4121

75. Ina Y, Tanooka H, Yamada T, Sakai K (2005) Suppression of thymic lymphoma induction by life-long low-dose-rate irradiation accompanied by immune activation in C57BL/6 mice. Radiat Res 163:153-158. doi:10.1667/RR3289

76. Ishii K, Hosoi Y, Yamada S, Ono T, Sakamoto K (1996) Decreased incidence of thymic lymphoma in AKR mice as a result of chronic, fractionated low-dose total-body $\mathrm{X}$ irradiation. Radiat Res 146:582-585. doi:10.2307/3579560

77. Jin SZ, Pan XN, Wu N, Jin GH, Liu SZ (2007) Whole-body low dose irradiation promotes the efficacy of conventional radiotherapy for cancer and possible mechanisms. Dose Response 5:349-358. doi:10.2203/dose-response.07-020.Jin

78. Wu N, Jin SZ, Pan XN, Liu SZ (2008) Increase in efficacy of cancer radiotherapy by combination with wholebody low dose irradiation. Int J Radiat Biol 84:201-210. doi:10.1080/09553000801902133
79. Ogura K, Magae J, Kawakami Y, Koana T (2009) Reduction in mutation frequency by very low-dose gamma irradiation of Drosophila melanogaster germ cells. Radiat Res 171:1-8. doi:10.1667/RR1288.1

80. Fisher DR, Weller RE (2010) Carcinogenesis from inhaled (239) $\mathrm{PuO}(2)$ in beagles: Evidence for radiation homeostasis at low doses? Health Phys 99:357-362. doi:10.1097/ HP.0b013e3181bfa16b

81. Cheda A, Wrembel-Wargocka J, Lisiak E, Marciniak M, Nowosielska EM, Janiak MK (2004) Inhibition of the development of pulmonary tumour nodules and stimulation of the activity of NK cells and macrophages in mice by single low doses of low-LET radiation. Int J Low Radiat 1:171-179. doi:10.1504/ IJLR.2004.003868

82. Cheda A, Wrembel-Wargocka J, Lisiak E, Nowosielska EM, Marciniak M, Janiak MK (2004) Single low doses of X rays inhibit the development of experimental tumour metastases and trigger the activities of NK cells in mice. Radiat Res 161:335340. doi:10.1667/RR3123

83. Cheda A, Wrembel-Wargocka J, Nowosielska EM, Janiak MK (2006) Immune mechanism of the retarded growth of tumor nodules in mice exposed to single low-level irradiations with X-rays. Centr. Eur J Immunol 31:44-50

84. Janiak MK, Wrembel-Wargocka J, Cheda A, Nowosielska EM, Lisiak E, Bilski M (2006) Modulation of anti-tumour functions of NK cells and macrophages after single low-level exposures of mice to X-rays. Int J Low Radiat 3:178-191. doi:10.1504/ IJLR.2006.012017

85. Nowosielska EM, Wrembel-Wargocka J, Cheda A, Lisiak E, Janiak MK (2005) Low-level exposures to ionising radiation modulate the anti-tumour activity of murine NK cells. Nukleonika 50(suppl 2):21-24

86. Nowosielska EM, Wrembel-Wargocka J, Cheda A, Lisiak E, Janiak MK (2006) Enhanced cytotoxic activity of macrophages and suppressed tumour metastases in mice irradiated with low doses of X-rays. J Radiat Res 47:229-236. doi:10.1269/jrr.0572

87. Nowosielska EM, Cheda A, Wrembel-Wargocka J, Janiak MK (2008) Modulation of the growth of pulmonary tumour colonies in mice after single or fractionated low-level irradiations with X-rays. Nukleonika 53(suppl 1):s9-s15

88. Nowosielska EM, Cheda A, Wrembel-Wargocka J, Janiak MK (2009) Immunological mechanism of the low-dose radiationinduced suppression of cancer metastases in a mouse model. Dose Response 8:209-226. doi:10.2203/dose-response.09-016. Nowosielska

89. Nowosielska EM, Cheda A, Wrembel-Wargocka J, Janiak MK (2011) Anti-neoplastic and immuno-stimulatory effects of lowdose X-ray fractions in mice. Int J Radiat Biol 87:202-212. doi: 10.3109/09553002.2010.519422

90. Nowosielska EM, Cheda A, Wrembel-Wargocka J, Janiak MK (2012) Effect of low doses of low-let radiation on the innate anti-tumor reactions in radioresistant and radiosensitive mice. Dose Response 10:500-515. doi:10.2203/doseresponse.12-018. Nowosielska

91. Bruce VR, Belinsky SA, Gott K, Liu Y, March T, Scott B, Wilder J (2012) Low-dose gamma-radiation inhibits benzo[a] pyrene-induced lung adenoma development in A/J mice. Dose Response 10:516-526. doi:10.2203/dose-response.12-040. Bruce

92. Bauer G (2007) Low dose radiation and intercellular induction of apoptosis: potential implications for the control of oncogenesis. Int $\mathrm{J}$ Radiat Biol 83:873-888. doi:10.1080/09553000701727523

93. Scott BR (2008) Low-dose-radiation stimulated natural chemical and biological protection against lung cancer. Dose Response 6:299-318. doi:10.2203/dose-response.07-025.Scott 
94. Scott BR (2014) Radiation-hormesis phenotypes, the related mechanisms and implications for disease prevention and therapy. J Cell Commun Signal 8:341-352. doi:10.1007/ s12079-014-0250-x

95. Shao M, Lu X, Cong W, Xing X, Tan Y, Li Y et al (2014) Multiple low-dose radiation prevents type 2 diabetes-induced renal damage through attenuation of dyslipidemia and insulin resistance and subsequent renal inflammation and oxidative stress. PLoS One 9(3):e92574. doi:10.1371/journal.pone.0092574

96. Safwat A (2000) The immunobiology of low-dose total-body irradiation: more questions than answers. Radiat Res 153:599604. doi:10.1667/0033-7587(2000)153[0599:TIOLDT]2.0 .CO;2

97. Liu SZ (2003) On radiation hormesis expressed in the immune system. Crit Rev Toxicol 33:431-441. doi:10.1080/713611045

98. Liu XD, Ma SM, Liu SZ (2003) Effects of 0.075 Gy X-ray irradiation on the expression of IL-10 and IL-12 in mice. Phys Med Biol 48:2041-2049. doi:10.1088/0031-9155/48/13/315

99. Liu SZ (2006) Cancer control related to stimulation of immunity by low-dose radiation. Dose Response 5:39-47. doi:10.2203/dose-response.06-108.Liu

100. Sakamoto K (2004) Radiobiological basis for cancer therapy by total or half-body irradiation. Nonlinearity Biol Toxicol Med 2:293-316. doi:10.1080/15401420490900254

101. Pollycove M (2006) Radiobiological basis of low-dose irradiation in prevention and therapy of cancer. Dose Response 5:2638. doi:10.2203/dose-response.06-112.Pollycove

102. Chaffey JT, Rosenthal DS, Moloney WC, Hellman S (1976) Total body irradiation as treatment for lymphosarcoma. Int J Radiat Oncol Biol Phys 1:399-405. doi:10.1016/0360-3016(76)90004-3

103. Choi NC, Timothy AR, Kaufman SD, Carey RW, Aisenberg AC (1979) Low dose fractionated whole body irradiation in the treatment of advanced non-Hodgkin's lymphoma. Cancer 43:1636-1642. doi:10.1002/1097-0142(197905)

104. Cuttler JM, Pollycove M (2003) Can cancer be treated with low doses of radiation? JPandS 8:108-111.

105. Safwat A, Bayoumy Y, El-Sharkawy N, Shaaban K, Mansour O, Kamel A (2003) The potential palliative role and possible immune modulatory effects of low-dose total body irradiation in relapsed or chemo-resistant non-Hodgkin's lymphoma. Radiother Oncol 69:33-36. doi:10.1016/S0167-8140(03)00247-0

106. Farooque A, Mathur R, Verma A, Kaul V, Bhatt AN, Adhikari JS et al (2011) Low-dose radiation therapy of cancer: role of immune enhancement. Expert Rev Anticancer Ther 11:791802. doi:10.1586/era.10.217

107. Gatti RA, Good RA (1971) Occurrence of malignancy in immunodeficiency diseases. A literature review. Cancer 28:89-98. doi:10.1002/1097-0142(197107)28:1<89::AIDCNCR2820280117>3.0.CO;2-Q

108. Stutman O (1974) Tumour development after 3-methylcholanthrene in immunologically deficient athymic mice. Science 183:534-536. doi:10.1126/science.183.4124.534

109. Algarra I, García-Lora A, Cabrera T, Ruiz-Cabello F, Garrido F (2004) The selection of tumour variants with altered expression of classical and nonclassical MHC class I molecules: implications for tumour immune escape. Cancer Immunol Immunother 53:904-910. doi:10.1007/s00262-004-0517-9

110. Aptsiauri N, Cabrera T, Garcia-Lora A, Lopez-Nevot MA, Ruiz-Cabello F, Garrido F (2007) MHC class I antigens and immune surveillance in transformed cells. Int Rev Cytol 256:139-189. doi:10.1016/S0074-7696(07)56005-5

111. Matsushita H, Vesely MD, Koboldt DC, Rickert CG, Uppaluri $\mathrm{R}$, Magrini VJ et al (2012) Cancer exome analysis reveals a T-cell-dependent mechanism of cancer immunoediting. Nature 482:400-404. doi:10.1038/nature10755
112. Marcus A, Gowen BG, Thompson TW, Iannello A, Ardolino $M$, Deng W et al (2014) Recognition of tumours by the innate immune system and natural killer cells. Adv Immunol 122:91-128. doi:10.1016/B978-0-12-800267-4.00003-1

113. Seong SY, Matzinger P (2004) Hydrophobicity: an ancient damage-associated molecular pattern that initiates innate immune responses. Nat Rev Immunol 4:469-478. doi:10.1038/nri1372

114. Parker KH, Sinha P, Horn LA, Clements VK, Yang H, Li J et al (2014) HMGB1 enhances immune suppression by facilitating the differentiation and suppressive activity of myeloid-derived suppressor cells. Cancer Res 74:5723-5733. doi:10.1158/00085472.CAN-13-2347

115. Jia L, Clear A, Liu FT, Matthews J, Uddin N, McCarthy A et al (2014) Extracellular HMGB1 promotes differentiation of nurselike cells in chronic lymphocytic leukemia. Blood 123:17091719. doi:10.1182/blood-2013-10-529610

116. Pardoll D (2003) Does the immune system see tumours as foreign or self? Annu Rev Immunol 21:807-839. doi:10.1146/ annurev.immunol.21.120601.141135

117. Ohm JE, Carbone DP (2001) VEGF as a mediator of tumorassociated immunodeficiency. Immunol Res 23:263-272. doi:10.1385/IR:23:2-3:263

118. Kim R, Emi M, Tanabe K, Arihiro K (2006) Tumour-driven evolution of immunosuppressive networks during malignant progression. Cancer Res 66:5527-5536. doi:10.1158/00085472.CAN-05-4128

119. Mahoney KM, Freeman GJ, McDermott DF (2015) The next immune-checkpoint inhibitors: PD-1/PD-L1 blockade in melanoma. Clin Ther 37:764-782. doi:10.1016/j. clinthera.2015.02.018

120. Postow MA, Callahan MK, Wolchok JD (2015) Immune checkpoint blockade in cancer therapy. J Clin Oncol 33:1974-1982. doi:10.1200/JCO.2014.59.4358

121. Ott PA, Hodi FS, Robert C (2013) CTLA-4 and PD-1/PD-L1 blockade: new immunotherapeutic modalities with durable clinical benefit in melanoma patients. Clin Cancer Res 19:53005309. doi:10.1158/1078-0432.CCR-13-0143

122. Gelao L, Criscitiello C, Esposito A, Goldhirsch A, Curigliano G (2014) Immune checkpoint blockade in cancer treatment: a double-edged sword cross-targeting the host as an "innocent bystander". Toxins 6: 914-933. doi:10.3390/toxins6030914

123. Francisco LM, Sage PT, Sharpe AH (2010) The PD-1 pathway in tolerance and autoimmunity. Immunol Rev 236:219-242. doi:10.1111/j.1600-065X.2010.00923.x

124. Roychoudhuri R, Eil RL, Restifo NP (2015) The interplay of effector and regulatory $\mathrm{T}$ cells in cancer. Curr Opin Immunol 33:101-111. doi:10.1016/j.coi.2015.02.003

125. Takeuchi Y, Nishikawa H (2016) Roles of regulatory T cells in cancer immunity. Int Immunol 28:401-409. doi:10.1093/ intimm/dxw025

126. Vignali DA, Collison LW, Workman CJ (2008) How regulatory T cells work. Nat Rev Immunol 8:523-532. doi:10.1038/ nri2343

127. Pyzer AR, Cole L, Rosenblatt J, Avigan DE (2016) Myeloidderived suppressor cells as effectors of immune suppression in cancer. Int J Cancer 139:1915-1926. doi:10.1002/ijc.30232

128. Achyut BR, Arbab AS (2016) Myeloid cell signatures in tumor microenvironment predicts therapeutic response in cancer. Onco Targets Ther 9:1047-1055. doi:10.2147/OTT.S102907

129. Meirow Y, Kanterman J, Baniyash M (2015) Paving the road to tumor development and spreading: myeloid-derived suppressor cells are ruling the fate. Front Immunol 6:523. doi:10.3389/ fimmu.2015.00523

130. Umansky V, Blattner C, Fleming V, Hu X, Gebhardt C, Altevogt P et al (2016) Myeloid-derived suppressor cells and 
tumor escape from immune surveillance. Semin Immunopathol. doi:10.1007/s00281-016-0597-6

131. Kim J, Bae JS (2016) Tumor-Associated Macrophages and Neutrophils in Tumor Microenvironment. Mediators Inflamm 2016:6058147. doi:10.1155/2016/6058147

132. Mantovani A, Sozzani S, Locati M, Allavena P, Sica A (2002) Macrophage polarization: tumour-associated macrophages as a paradigm for polarized M2 mononuclear phagocytes. Trends Immunol 23:549-555. doi:10.1016/S1471-4906(02)02302-5

133. Sainz B Jr, Carron E, Vallespinós M, Machado HL (2016) Cancer stem cells and macrophages: Implications in tumor biology and therapeutic strategies. Mediators Inflamm 2016:9012369. doi:10.1155/2016/9012369

134. Terabe M, Berzofsky JA (2008) The role of NKT cells in tumor immunity. Adv Cancer Res 101:277-348. doi:10.1016/ S0065-230X(08)00408-9

135. Macho-Fernandez E, Brigl M (2015) The extended family of CD1d-restricted NKT cells: Sifting through a mixed bag of TCRs, antigens, and functions. Front Immunol 6:362. doi:10.3389/fimmu.2015.00362

136. Shissler SC, Bollino DR, Tiper IV, Bates JP, Derakhshandeh R, Webb TJ (2016) Immunotherapeutic strategies targeting natural killer T cell responses in cancer. Immunogenetics 68:623-638. doi:10.1007/s00251-016-0928-8

137. Wu S, Rhee KJ, Albesiano E, Rabizadeh S, Wu X, Yen HR et al (2009) A human colonic commensal promotes colon tumourigenesis via activation of $\mathrm{T}$ helper type $17 \mathrm{~T}$ cell responses. Nat Med 15:1016-1022. doi:10.1089/cbr.2014.1702

138. Maniati E, Soper R, Hagemann T (2010) Up for mischief? IL-17/Th17 in the tumour microenvironment. Oncogene 29:5653-5662. doi:10.1038/onc.2010.367

139. Zou W, Restifo NP (2010) $\mathrm{T}(\mathrm{H}) 17$ cells in tumour immunity and immunotherapy. Nat Rev Immunol 10:248-256. doi:10.1038/nri2742

140. Zhang Y, Morgan R, Podack ER, Rosenblatt J (2013) B cell regulation of anti-tumor immune response. Immunol Res 57:115124. doi:10.1007/s12026-013-8472-1

141. Candando KM, Lykken JM, Tedder TF (2014) B10 cell regulation of health and disease. Immunol Rev 259:259-272. doi:10.1111/imr.12176

142. Zhang Y, Eliav Y, Shin SU, Schreiber TH, Podack ER, Tadmor T, Rosenblatt JD (2013) B lymphocyte inhibition of anti-tumor response depends on expansion of Treg but is independent of B-cell IL-10 secretion. Cancer Immunol Immunother 62:87-99. doi:10.1007/s00262-012-1313-6

143. Zhang Y, Morgan R, Chen C, Cai Y, Clark E, Khan WN et al (2016) Mammary-tumor-educated B cells acquire LAP/TGF- $\beta$ and PD-L1 expression and suppress anti-tumor immune responses. Int Immunol 28:423-423. doi:10.1093/intimm/ dxw007

144. Sionov RV, Fridlender ZG, Granot Z (2015) The multifaceted roles neutrophils play in the tumour microenvironment. Cancer Microenviron 8:125-158. doi:10.1007/s12307-014-0147-5

145. Coffelt SB, Wellenstein MD, De Visser KE (2016) Neutrophils in cancer: neutral no more. Nat Rev Cancer 16:431-446. doi:10.1038/nrc.2016.52

146. Piccard H, Muschel RJ, Opdenakker G (2012) On the dual roles and polarized phenotypes of neutrophils in tumour development and progression. Crit Rev Oncol Hematol 82:296-309. doi:10.1016/j.critrevonc.2011.06.004

147. Dumitru CA, Lang S, Brandau S (2013) Modulation of neutrophil granulocytes in the tumour microenvironment: mechanisms and consequences for tumour progression. Semin Cancer Biol 23:141-148. doi:10.1016/j.semcancer.2013.02.005

148. Hurwitz AA, Watkins SK (2012) Immune suppression in the tumour microenvironment: a role for dendritic cell-mediated tolerization of T cells. Cancer Immunol Immunother 61:289293. doi:10.1007/s00262-011-1181-5

149. Huang XM, Liu XS, Lin XK, Yu H, Sun JY, Liu XK et al (2014) Role of plasmacytoid dendritic cells and inducible costimulator-positive regulatory $\mathrm{T}$ cells in the immunosuppression microenvironment of gastric cancer. Cancer Sci 105:150-158. doi:10.1111/cas.12327

150. Ostrand-Rosenberg S, Sinha P, Beury DW, Clements VK (2012) Cross-talk between myeloid-derived suppressor cells (MDSC), macrophages, and dendritic cells enhances tumourinduced immune suppression. Semin Cancer Biol 22:275281. doi:10.1016/j.semcancer.2012.01.011

151. Ramos RN, de Moraes CJ, Zelante B, Barbuto JA (2013) What are the molecules involved in regulatory T-cells induction by dendritic cells in cancer? Clin Dev Immunol 2013:806025. doi:10.1155/2013/806025

152. Dalton DK, Noelle RJ (2012) The roles of mast cells in anticancer immunity. Cancer Immunol Immunother 61:15111520. doi:10.1007/s00262-012-1246-0

153. Yi T, Song SU (2012) Immunomodulatory properties of mesenchymal stem cells and their therapeutic applications. Arch Pharm Res 35:213-221. doi:10.1007/s12272-012-0202-z

154. Barcellos-de-Souza P, Gori V, Bambi F, Chiarugi P (2013) Tumour microenvironment: bone marrow-mesenchymal stem cells as key players. Biochim Biphys Acta 1836:321-335. doi:10.1016/j.bbcan.2013.10.004

155. Puré E, Lo A (2016) Can targeting stroma pave the way to enhanced antitumor immunity and immunotherapy of solid tumors? Cancer Immunol Res 4:269-278. doi:10.1158/23266066.CIR-16-0011

156. Mantovani A, Allavena P, Sica A, Balkwill F (2008) Cancerrelated inflammation. Nature 454:436-444. doi:10.1038/ nature 07205

157. Candido J, Hagemann T (2013) Cancer-related inflammation. J Clin Immunol 33(Suppl 1):S79-S84. doi:10.1007/ s10875-012-9847-0

158. Colotta F, Allavena P, Sica A, Garlanda C, Mantovani (2009) A Cancer-related inflammation, the seventh hallmark of cancer: links to genetic instability. Carcinogenesis 30:10731081. doi:10.1093/carcin/bgp127

159. Grivennikov SI, Greten FR, Karin M (2010) Immunity, inflammation, and cancer. Cell 140:883-899. doi:10.1016/j. cell.2010.01.025

160. Pal S, Bhattacharjee A, Ali A, Mandal NC, Mandal SC, Pal M (2014) Chronic inflammation and cancer: potential chemoprevention through nuclear factor kappa B and p53 mutual antagonism. J Inflamm (Lond) 11:23. doi:10.1186/1476-9255-11-23

161. Khan S, Jain M, Mathur V, Feroz SM (2016) Chronic inflammation and cancer: paradigm on tumor progression, metastasis and therapeutic intervention. Gulf J Oncolog 1:86-93

162. Romano M, DE Francesco F, Zarantonello L, Ruffolo C, Ferraro GA, Zanus G et al (2016) From inflammation to cancer in inflammatory bowel disease: molecular perspectives. Anticancer Res 36:1447-1460

163. Bunt SK, Clements VK, Hanson EM, Sinha P, OstrandRosenberg S (2009) Inflammation enhances myeloid-derived suppressor cell cross-talk by signaling through Toll-like receptor 4. J Leukoc Biol 85:996-1004. doi:10.1189/ jlb.0708446

164. Ostrand-Rosenberg S, Sinha P (2009) Myeloid-derived suppressor cells: linking inflammation and cancer. J Immunol 182:4499-4506. doi:10.4049/jimmunol.0802740

165. Kent A, Blander JM (2014) Nod-like receptors: key molecular switches in the conundrum of cancer. Front Immunol 5:185189. doi:10.3389/fimmu.2014.00185 
166. Saxena M, Yeretssian G (2014) NOD-like receptors: master regulators of inflammation and cancer. Front Immunol 5:327342. doi:10.3389/fimmu.2014.00327

167. Feinendegen LE, Pollycove M, Neumann RD (2009) Lowdose cancer risk modeling must recognize up-regulation of protection. Dose Response 8:227-252. doi:10.2203/doseresponse.09-035.Feinendegen

168. Mitchel RE, Jackson JS, Carlisle SM (2004) Upper dose threshold for radiation-induced adaptive response against cancer in high-dose-exposed, cancer-prone, radiation-sensitive Trp53 heterozygous mice. Radiat Res 162:20-30. doi:10.1667/RR3190

169. Taylor LS (1980) Some nonscientific influences on radiation protection standards and practice. The 1980 Sievert Lecture. Health Phys 39:851-874

170. Zhang C, Jin S, Guo W, Li C, Li X, Rane MJ et al (2011) Attenuation of diabetes-induced cardiac inflammation and pathological remodeling by low-dose radiation. Radiat Res 175:307-321. doi:10.1667/RR1950.1

171. Calabrese EJ (2015) An abuse of risk assessment: how regulatory agencies improperly adopted LNT for cancer risk assessment. Arch Toxicol 89:647-648. doi:10.1007/ s00204-015-1454-4

172. Anderson RE, Tokuda S, Williams WL, Warner NL (1982) Radiation-induced augmentation of the response of $\mathrm{A} / \mathrm{J}$ mice to SaI tumor cells. Am J Pathol 108:24-37

173. Kharazi AI, James SJ, Taylor JM, Lubinski JM, Nakamura LT, Makinodan T (1994) Combined chronic low dose radiation-caloric restriction: a model for regression of spontaneous mammary tumor. Int J Radiat Oncol Biol Phys 28:641-647. doi:10.1016/0360-3016(94)90189-9

174. Lacoste-Collin L, Jozan S, Cances-Lauwers V, Pipy B, Gasset G, Caratero C, Courtade-Saïdi M (2007) Effect of continuous irradiation with a very low dose of gamma rays on life span and the immune system in SJL mice prone to B-cell lymphoma. Radiat Res 168:725-732. doi:10.1667/RR1007.1

175. Wang B, Li B, Dai Z, Ren S, Bai M, Wang Z et al (2014) Low-dose splenic radiation inhibits liver tumor development of rats through functional changes in CD4 + CD25 + Treg cells. Int J Biochem Cell Biol 55:98-108. doi:10.1016/j. biocel.2014.08.014

176. Cheda A, Wrembel-Wargocka J, Nowosielska EM, Janiak MK (2005) Stimulatory effects of a single low-level irradiations with X-rays on functions of murine peritoneal macrophages. Nukleonika 50(suppl 2):13-16.

177. Cheda A, Nowosielska EM, Wrembel-Wargocka J, Janiak MK (2008) Production of cytokines by peritoneal macrophages and splenocytes after exposures of mice to low doses of X-rays. Radiat Environ Biophys 47:275-283. doi:10.1007/ s00411-007-0147-7

178. Cheda A, Nowosielska EM, Wrembel-Wargocka J, Janiak MK (2009) Single or fractionated irradiations of mice with low doses of X-rays stimulate innate immune mechanisms. Int $\mathbf{J}$ Low Radiat 6:325-342. doi:10.1504/IJLR.2009.029312

179. Nowosielska EM, Wrembel-Wargocka J, Cheda A, Janiak MK (2006) A single low-dose irradiation with X-rays stimulates NK cells and macrophages to release factors related to the cytotoxic functions of these cells. Centr Eur J Immunol 31:51-56

180. Pollycove M, Feinendegen LE (2011) Low-dose radiotherapy of disease. Health Phys 100:322-324. doi:10.1097/ HP.0b013e318208423b

181. Holder DL (1965) Total body irradiation in multiple myeloma. Radiology 84:82-86

182. Kazem I (1975) Total body irradiation in the management of malignant lymphoma. Radiol Clin 44:457-463.

183. Qasim MM (1975) Total body irradiation in non-Hodgkin lymphoma. Strahlentherapie 149:364-367.
184. Richaud PM, Soubeyran P, Eghbali H, Chacon B, Marit G, Broustet A, Hoerni B (1998) Place of low-dose total body irradiation in the treatment of localized follicular non-Hodgkin's lymphoma: results of a pilot study. Int J Radiat Oncol Biol Phys 40:387-390. doi:10.1016/S0360-3016(97)00722-0

185. Jaworowski Z (1999) Radiation risk and ethics. Phys Today 52:24-29

186. Tanooka H (2001) Threshold dose-response in radiation carcinogenesis: an approach from chronic beta-irradiation experiments and a review of non-tumour doses. Int J Radiat Biol 77:541-551. doi:10.1080/09553000110034612

187. Scott BR (2008) It's time for a new low-dose-radiation risk assessment paradigm—one that acknowledges hormesis. Dose Response 6:333-351. doi:10.2203/dose-response.07-005. Scott

188. Tubiana M, Feinendegen LE, Yang C, Kaminski JM (2009) The linear no-threshold relationship is inconsistent with radiation biologic and experimental data. Radiology 251:13-22. doi:10.1148/radiol.2511080671

189. Cuttler JM (2010) Commentary on using LNT for radiation protection and risk assessment. Dose Response 8:378-383. doi:10.2203/dose-response.10-003.Cuttler

190. Ulsh BA (2012) The new radiobiology: returning to our roots. Dose Response 10:593-609. doi:10.2203/doseresponse.12-021.Ulsh

191. Calabrese EJ (2013) Origin of the linearity no threshold (LNT) dose-response concept. Arch Toxicol 87:1621-1633. doi:10.1007/s00204-013-1104-7

192. Socol Y, Dobrzyński L, Doss M, Feinendegen LE, Janiak MK, Miller ML et al (2013) Commentary: ethical issues of current health-protection policies on low-dose ionizing radiation. Dose Response 12:342-348. doi:10.2203/dose-response.13-044. Socol

193. Kesavan PC (2014) Linear, no threshold response at low doses of ionizing radiation: ideology, prejudice and science. Curr Sci India 107:46-53.

194. Mitchel REJ (2007) Cancer and low dose responses in vivo: implications for radiation protection. Dose Response 5:284 291. doi:10.2203/dose-response.07-014.Mitchel

195. Marcus CS (2015) Time to reject the linear-no threshold hypothesis and accept thresholds and hormesis: a petition to the U.S. Nuclear Regulatory Commission. Clin Nucl Med 40:617619. doi:10.1097/RLU.0000000000000835

196. Sonn CH, Choi JR, Kim TJ, Yu YB, Kim K, Shin SC et al (2012) Augmentation of natural cytotoxicity by chronic lowdose ionizing radiation in murine natural killer cells primed by IL-2. J Radiat Res 53:823-829. doi:10.1093/jrr/rrs037

197. Yang G, Kong Q, Wang G, Jin H, Zhou L, Yu D et al (2014) Low-dose ionizing radiation induces direct activation of natural killer cells and provides a novel approach for adoptive cellular immunotherapy. Cancer Biother Radiopharm 29:428-434. doi:10.1089/cbr.2014.1702

198. Liu SZ, Jin SZ, Liu XD, Sun YM (2001) Role of CD28/ B7 costimulation and IL-12/IL-10 interaction in the radiation-induced immune changes. BMC Immunol 2:8. doi:10.1186/1471-2172-2-8

199. Sambani C, Thomou H, Kitsiou P (1996) Stimulatory effect of low dose X-irradiation on the expression of the human T lymphocyte CD2 surface antigen. Int J Radiat Biol 70:711-717. doi:10.1080/095530096144608

200. Gasser S, Orsulic S, Brown EJ, Raulet DH (2005) The DNA damage pathway regulates innate immune system ligands of the NKG2D receptor. Nature 436:1186-1190. doi:10.1038/ nature 03884

201. Schaue D, Ratikan JA, Iwamoto KS, McBride WH (2012) Maximizing tumour immunity with fractionated radiation. 
Int J Radiat Oncol Biol Phys 83:1306-1310. doi:10.1016/j. ijrobp.2011.09.049

202. Hellweg CE (2015) The nuclear factor $\kappa B$ pathway: a link to the immune system in the radiation response. Cancer Lett 368:275289. doi:10.1016/j.canlet.2015.02.019

203. Chen Y, Chen X, Li Y, Zhang H, Xie Y, Zhang X et al (2011) Early effects of low dose $\mathrm{C}$ ion or $\mathrm{X}$-ray irradiation on peripheral blood lymphocytes of patients with alimentary tract cancer. Dose Response 9:356-368. doi:10.2203/dose-response.10-015. Chen

204. Chen Y, Wang C, He M, Zhang H, Chen X (2014) Effect of low dose heavy ion irradiation on subset percentage and cytokines expression of peripheral blood lymphocytes in patients with pancreatic cancer. Zhonghua Zhong Liu Za Zhi 36:435-439

205. Awuah SG, Zheng YR, Bruno PM, Hemann MT, Lippard SJ (2015) A Pt(IV) pro-drug preferentially targets indoleamine2,3-dioxygenase, providing enhanced ovarian cancer immunochemotherapy. J Am Chem Soc 137:14854-14857. doi:10.1021/ jacs.5b10182

206. Xiao P, Wan X, Cui B, Liu Y, Qiu C, Rong J et al (2015) Interleukin 33 in tumor microenvironment is crucial for the accumulation and function of myeloid-derived suppressor cells. Oncoimmunology 5:e1063772. doi:10.1080/21624 02X.2015.1063772

207. Achkova D, Maher J (2016) Role of the colony-stimulating factor $(\mathrm{CSF}) / \mathrm{CSF}-1$ receptor axis in cancer. Biochem Soc Trans 44:333-341. doi:10.1042/BST20150245

208. Drakes ML, Stiff PJ (2014) Harnessing immunosurveillance: current developments and future directions in cancer immunotherapy. Immunotargets Ther 3:151-165. doi:10.2147/ITT. S37790

209. Klug F, Prakash H, Huber PE, Seibel T, Bender N, Halama N et al (2013) Low-dose irradiation programs macrophage differentiation to an iNOS $/ \mathrm{M} 1$ phenotype that orchestrates effective T cell immunotherapy. Cancer Cell 24:589-602. doi:10.1016/j. ccr.2013.09.014

210. De Palma M, Lewis CE (2013) Macrophage regulation of tumour responses to anticancer therapies. Cancer Cell 23:277286. doi:10.1016/j.ccr.2013.02.013

211. Tazzyman S, Niaz H, Murdoch C (2013) Neutrophil-mediated tumour angiogenesis: subversion of immune responses to promote tumour growth. Semin Cancer Biol 23:149-158. doi:10.1016/j.semcancer.2013.02.003

212. Duan MC, Zhong XN, Liu GN, Wei JR (2014) The Treg/ Th17 paradigm in lung cancer. J Immunol Res 2014:730380. doi:10.1155/2014/730380
213. Zhou J, He LL, Ding XF, Yuan QQ, Zhang JX, Liu SC, Chen G (2016) Combinatorial antitumor effect of rapamycin and $\beta$-elemene in follicular thyroid cancer cells. Biomed Res Int 2016:6723807. doi:10.1155/2016/6723807

214. Matsuo K, Itoh T, Koyama A, Imamura R, Kawai S, Nishiwaki $\mathrm{K}$ et al (2016) CCR4 is critically involved in effective antitumor immunity in mice bearing intradermal B16 melanoma. Cancer Lett 378:16-22. doi:10.1016/j.canlet.2016.04.039

215. Shan YX, Jin SZ, Liu XD, Liu Y, Liu SZ (2007) Ionizing radiation stimulates secretion of pro-inflammatory cytokines: doseresponse relationship, mechanisms and implications. Radiat Environ Biophys 46:21-29. doi:10.1007/s00411-006-0076-x

216. Roses RE, Datta J, Czerniecki BJ (2014) Radiation as immunomodulator: implications for dendritic cell-based immunotherapy. Radiat Res 182:211-218. doi:10.1667/RR13495.1

217. Schölch S, Rauber C, Weitz J, Koch M, Huber PE (2015) TLR activation and ionizing radiation induce strong immune responses against multiple tumor entities. Oncoimmunology 4:e1042201. doi:10.1080/2162402X.2015.1042201

218. Zhang C, Tan Y, Guo W, Li C, Ji S, Li X, Cai L (2009) Attenuation of diabetes-induced renal dysfunction by multiple exposures to low-dose radiation is associated with the suppression of systemic and renal inflammation. Am J Physiol Endocrinol Metab 297:E1366-E1377. doi:10.1152/ajpendo.00478

219. Xing X, Zhang C, Shao M, Tong Q, Zhang G, Li C et al (2012) Low-dose radiation activates Akt and Nrf2 in the kidney of diabetic mice: a potential mechanism to prevent diabetic nephropathy. Oxid Med Cell Longev 2012:291087. doi:10.1155/2012/291087

220. Kim JE, Patel MA, Mangraviti A, Kim ES, Theodros D, Velarde E et al (2017) Combination therapy with anti-PD-1, anti-TIM-3, and focal radiation results in regression of murine gliomas. Clin Cancer Res 23:124-136. doi:10.1158/1078-0432.CCR-15-1535

221. Zheng W, Skowron KB, Namm JP, Burnette B, Fernandez C, Arina A et al (2016) Combination of radiotherapy and vaccination overcome checkpoint blockade resistance. Oncotarget 7:43039-43051. doi:10.18632/oncotarget.9915

222. Hettich M, Lahoti J, Prasad S, Niedermann G (2016) Checkpoint antibodies but not $\mathrm{T}$ cell-recruiting diabodies effectively synergize with TIL-inducing $\gamma$-irradiation. Cancer Res 76:4673-4683. doi:10.1158/0008-5472.CAN-15-3451 